\title{
Female Song in the Siberian Blue Robin Luscinia cyane
}

\author{
Minoru Tamura* and Keisuke Ueda*
}

\begin{abstract}
Key words: Siberian Blue Robin, Luscinia cyane, Female song, Nest defense, Parental care, Sexual dimorphism.

キーワード：コルリ，メスの囀り，巣の防衛，親の世話，性的二型.
\end{abstract}

In many passerine birds only males has been thought to sing, except for some tropical bird species (Kroodsma et al. 1996, Morton 1996). Though there were several reports on female song in temperate region, it had been considered to be rare among passerines (Richison 1983, Arcese et al. 1988). However, there is growing evidence of occasional female song in recent years (Beletsky 1982, 1983a, 1983b, Richison 1986, Hoelzel 1986, Hobson \& Sealy 1990a, 1990b, Kriner \& Schwabl 1991).

The Siberian Blue Robin Luscinia cyane is a summer resident in southern Siberia from Altai east to Amurland and Sakhalin, south to Manchuria, Korea, Japan, and northern China, wintering in south-east China west to Burma, Philippines, Borneo, and Sumatra (Cramp 1988). In Japan, it mainly occurs in central Honshu and Hokkaido. It breeds in sub-alpine zone at mountainous area from $c a$. 700 to $1800 \mathrm{~m}$ (a.s.l) in Honshu (Yamashina 1941). However, there is only one study of this species (Haneda \& Horiuchi 1968). which mainly focused on the nesting ecology.

We conducted a detailed study of breeding ecology of the Siberian Blue Robin at Kiyosato, central Japan $\left(35^{\circ} 65^{\prime} \mathrm{N}, 138^{\circ} 25^{\prime} \mathrm{E}\right)$, in 1998 . In the course of our study, we noticed that some females sang infrequently. Here we describe and examine the context of song in female Siberian Blue Robins, to our knowledge unreported in this species.

We made observations of Siberian Blue Robins during the breeding season in 1998, at Kawamata Valley (1,350-1,450 m, a.s.1.) and Utsukushi-mori forest (1,550-1,650 m, a.s. 1.). The study area is a steep slope of sub-alpine forests upward the valley. Both forests are composed of coniferous and broad-leaved tree species, with dense shady canopy and fallen leaves and twigs but not so much undergrowth.

We carried out observations for a total of 40 days ( $c a .313 \mathrm{hrs}$.) between 8th May and 13th July 1998. Observations were made for 3 to 4 days per week. The behaviour of males was observed with binoculars $(8 \times \& 9 \times)$ from 10 to $20 \mathrm{~m}$ in distance. Immediately after the start of breeding, we tried to look for nests in the forest by walking on trails. Once a nest had been found we checked its contents regularly to determine the nesting cycle carefully. We took all effects to minimize human disturbance. Two males and one female belonging to two breeding pairs were captured by mist nets and banded with unique com-

Received 19 Oct. 2000, Revised 25 December 2000, Accepted 27 December 2000.

* Laboratory of Animal Ecology, Rikkyo University, Ikebukuro, Tokyo, 171-8501 Japan.

Address correspondence to K. Ueda: E-mail: keisuke@rikkyo.ac.jp 
binations of colour leg rings. Their breeding attempts were monitored by a video camera and was the song frequency of males and females was. The recording was made in front of the nests by a video tape recorder (SANYO-VM-PS102H).

A total of 14 males settled in the study area. Six males established territories almost simultaneously at Kawamata forest and later eight held territories successively at Utsukushi-mori forest. These males sang vigorously throughout the breeding season. They spent $c a .27 \%$ of their time for singing on the average. The song frequency of males was $11.56 \pm 5.39$ (times/5-min, $x \pm$ S.D.) in the morning and 5.67 \pm 3.81 (times/5-min, $x \pm \mathrm{S}$. D.) in the evening. The male song is started with monotonic "tsit, tsit" calls, which then abruptly changed into strong trills; the sonograms showed three song repertoires in male songs (Fig. 1).

Female song was recorded rarely during our work. The female song was detected in three females during the observation. All the cases of female songs were detected at Utsukushi-mori in late-June. In one case, a banded female sang apparently in response to human approach ca. $20 \mathrm{~m}$ from her nest. The female sang on a log in the forest floor, or on other perches near ground level frequently. Other two females were also observed to sing at their nest sites during feeding nestlings or attending fledgelings.

We identified four repertoires in a female song (Fig. 2). The female song was composed of trills of repetitive high-frequency notes as male's (Fig. 1). It was uttered at substantially lower frequency and weaker volume than male song (Figs. 1 \& 2). The "tsit, tsit" call (a prelude) was observed in every male song, but it was not found in two of four song repertoires in the female.
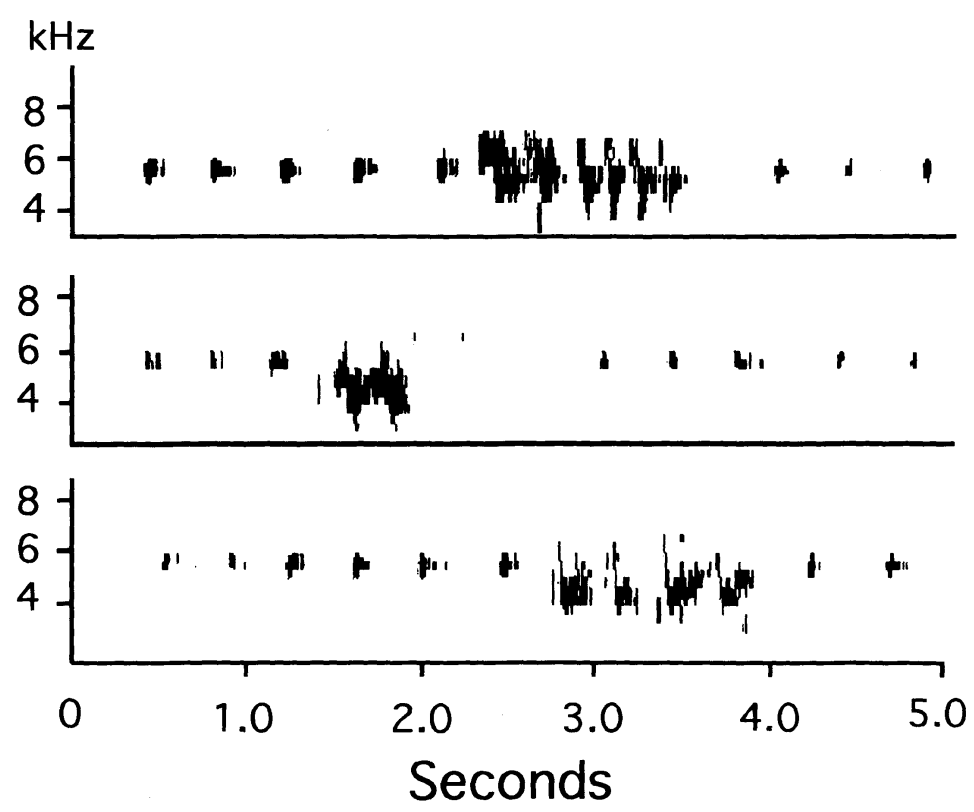

Fig. 1. Sonograms of male songs of the Siberian Blue Robin. 


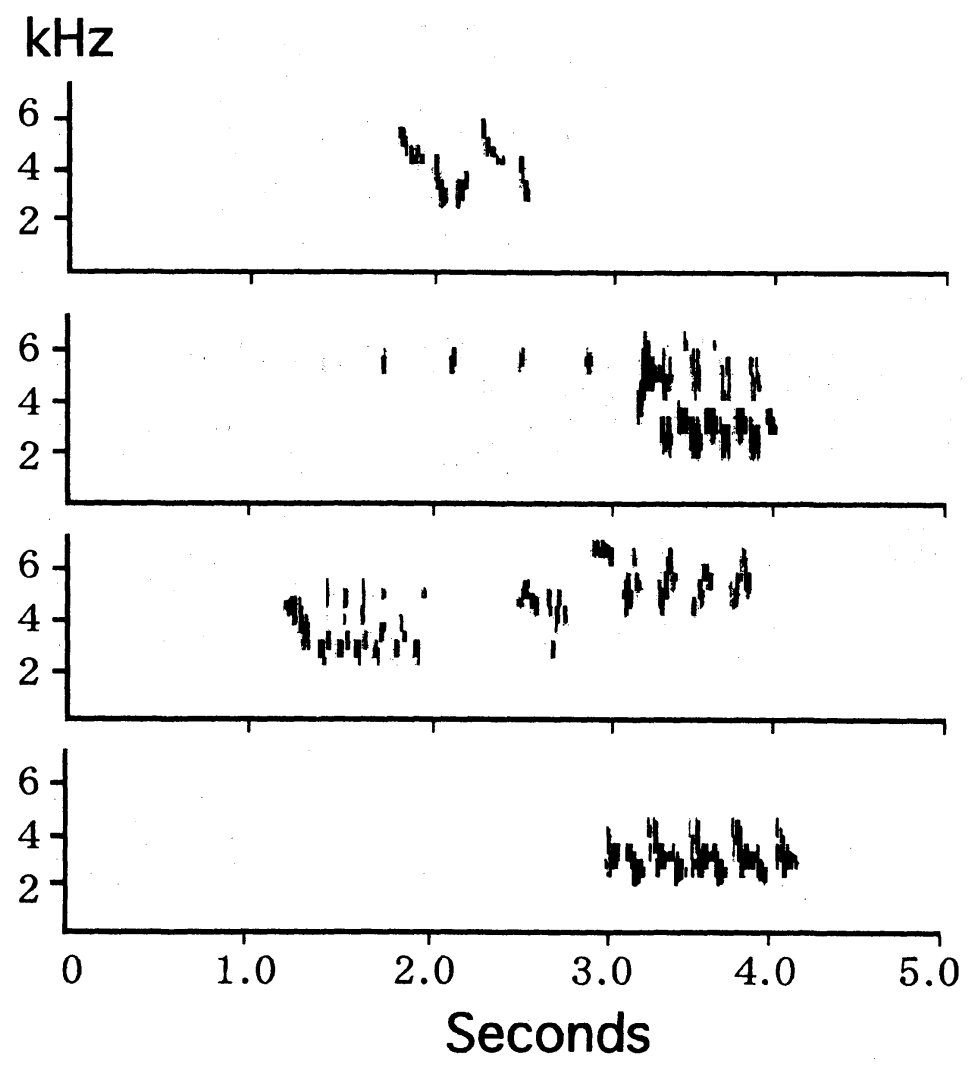

Fig. 2. Sonograms of female songs of the Siberian Blue Robin.

Female songs have been observed in some small thrushes. In the Japanese Robin $E$. rithacus akahige, a female sang weakly during the nest building and incubating periods in response to her mate's song (Haneda \& Kudo 1976). Similar observations on female song were recorded in the Ryukyu Robin E. komadori (N. Kawaji, pers. comm.), the Siberian Rubythroat L. calliope, the Bluethroat L. svecicus (Cramp 1988), and the Red-flanked Bush Robin Tarsiger cyanurus (the authors, pers. obs.). Accordingly female song seems to occur popularly in small thrushes.

Some hypothesized roles of female song have been considered (Langmore 1998). One hypothesis likely to explain the function is that female song serves territorial defence against conspecific intruders. However, we never observed conspecific intrusion in the Siberian Blue Robin.

In some species, females sing for defending separate territories against intruders of both sexes during non-breeding season. In the European Robin E. rabecula, females do not sing during the summer, but at the end of the breeding season the pair separates and the male and female defend feeding territories exclusively (Lack 1965). Similarly in the Red-flanked Bush Robin and the Daurian Redstart Phoenicurus auroreus, females hold 
foraging territory in wintering ground, and utter short whistles to intruders for preventing feeding territory (the authors, pers. obs.). However, in the Siberian Blue Robin, females sang only during the breeding season. It's function is not similar to these robins and the redstart.

In this study, all of the female songs were uttered at the nest sites during nestling and/ or fledgeling period during their mate's presence near the nests. It seemed to be a kind of nest defence by females to predators.

\section{Acknowledgements}

We thank the KEEP association for providing facilities. We are gratefull to $H$. Uchida, N. Aikawa, T. Saitou, M. Takagi, I. Nishiumi, Y. Kunitake for their assistance in the study area. Haruo Kuroda provided us a computer software of sonograms. N. Kachi kindly taught us scientific names of plants at the habitat.

\section{References}

Arcese, P., Stoddard, P. K. \& Hiebert, S. M. 1988. The form and function of song in female Song Sparrows. Condor 90: 51-57.

Beletsky, L. D. 1982. Vocalizations of female Northern Orioles. Condor 84: 445-447.

Beletsky, L. D. 1983a. Aggressive and pair-bond maintenance songs of female Red-winged Black-birds (Agelaius phoeniceus). Z. Tierpsychol. 63: 47-54.

Beletsky, L. D. 1983b. Aggressive response to "self" songs by female Red-winged Blackbirds (Agelaius phoeniceus). Can. J. Zool. 61: 462-465.

Cramp, S. (ed.) 1988. Birds of Europe the Middle East and North Africa. Vol. 5. Oxford Univ. Press, Oxford. $1063 \mathrm{pp}$.

Haneda, K. \& Horiuchi, Y. 1968. Breeding biology of the Siberian Blue Robin. Bull. Inst. Nat. Educ. Shiga Heights 8: 79-86. (In Japanese with English summary)

Haneda, K. \& Kudo, E. 1976. Breeding biology of Japanese Robin, Erithacus akahige. Bull. Inst. Nat. Educ. Shiga Heights 15: 9-19. (In Japanese with English summary)

Hobson, K. A. \& Sealy, S. G. 1990a. Female song in the Yellow Warbler. Condor 92: 259-261.

Hobson, K. A. \& Sealy, S. G., 1990b. Breeding-season aggression of female Yellow Warblers to models of male and female conspecific intruders. Anim. Behav. 39: 809-811.

Hoelzel, A. R. 1986. Song characteristics and response to playback of male aud female robins Erithacus rubecala. Ibis 128: 115-127.

Kriner, E. \& Schwabl, H. 1991. Control of winter song and territorial aggresion of female robins (Erithacus rubecala) by testosterone. Ethology 87: 37-44

Kroodsma, D. E., Vielliard, J. M. E. \& Stiles, F. G. 1996. Study of bird sounds in the neotropics: urgency and opportunity. In: Kroodsma and Miller (Eds.) Ecology and Evolution of Acoustic Communication in Birds. Cornell Univ. Press.

Lack, D. 1965. The Life of the Robin, Collins, London \& Glasgow, $219 \mathrm{pp}$.

Langmore, N. E. 1998. Functions of duet and solo songs of female birds. Trends Ecol. Evol. 13: 136-140.

Morton, E. S. 1996. A comparison of vocal behavior among tropical and temperate passerine birds. In Ecology and Evolution of Acoustic Communication in Birds. Kroodsma and Miller (Eds.) Cornell Univ. Press.

Richison, G. 1983. The function of singing in female Black-headed Grosbeaks (Pheucticus melanocephalus): family group maintenance. Auk 100: 105-116.

Richison, G. 1986. The singing behavior of female Northern Cardinals. Condor 88: 156-159.

Tamura, M. \& Ueda, K. 2001 (in press). Breeding ecology of the Siberian Blue Robin. Strix 19 ,(in Japanese 
with English summary)

Yamashina, Y. 1941. A natural history of Japanese birds. Iwanami-shoten, Tokyo, 1080 pp. (in Japanese)

\section{コルリにおけるメスの哂り}

一般に鳴禽類では, メスの㗕りは一般的ではないが, 著者らは 1998 年 5〜7月に, 山梨県清 里において,コルリの繁殖生態を調查中に, コルリのメスが囀るのを観察・記録することがで きた。観察したのは繁殖期の後半 (6月下旬) で，2つのなわばり内の巣で，メスが巣内ビナに 給餌を行っていた時期と，巣立ち雛を連れている時期に観察され，ビデオ撮影・録音された。 またヒナが巣立った直後に発見した別のなわばり内の巣のメスも，巣立ちビナを連れながら， さえずっているのが観察された。メスの㖇りにもいくつかのレパートリがあったが，才スの嚩 りと異なり，囀り 4 パターンの中， 2 パターンにおいて，オスの㗘りに特徴的な「チッ，チッ， チッ‥」という前奏が聞かれなかった。メスはオスよりも低い声で，また，オスよりも弱い声 で囀っていたが，嚩りのパターンは部分的にはよく似ている傾向が見られた。メスが嚩ること の意味は，まだよくわからないが，人の巣への接近という状況下で起こっていることから，メ スによる巣の防衛行動に関連した機能があると思われた。

田村 實 -上田恵介*：立教大学理学部動物生態学研究室 ₹171-8501 豊島区西池袋 3 丁目 34-1. * E-mail: keisuke@rikkyo.ac.jp 